\title{
Urbanização e industrialização: rios de São Paulo
}

Dossier EletromemóRIA: PAisAgem E HistóRIA

\section{Odette Carvalho de Lima Seabra}

Professora do Programa de Pós-Graduação em Geografia Humana - FFLCH-USP. São Paulo [SP] Brasil. <odseabra@usp.br>.

\section{Resumo}

A hidroeletricidade foi um suporte essencial para a industrialização de São Paulo. The São Paulo Tramway Light and Power Co. Ltd., empresa canadense que operou em regime de concessão no Brasil, viabilizou a montagem do sistema em cuja base estava o aproveitamento do potencial hidráulico da Bacia do Alto Tietê. Neste breve ensaio recupero momentos de uma pesquisa maior para mostrar os impulsos gerados e suas implicações em diferentes esferas da vida social. Interessou particularmente trazer à luz a questão da inversão do curso do Rio Pinheiros, condição essencial para realizar a captação das águas do Tietê.

\section{Palavras-chave}

Enchente, urbanização, eletrificação, modernização, concessão.

\section{Urbanization and industrialization: rivers of São Paulo}

\begin{abstract}
Hydroelectricity was an essential support for the industrialization of São Paulo. The São Paulo Tramway Light and Power Co. Ltd., a Canadian corporation which had concessions in Brazil, built up a system based on using the hydraulic potential of the upper Tietê basin. In this brief article I recover some moments of a larger research to show the generated impulses and their implications on different areas of social life. It was particularly relevant to bring out the question of inverting the course of Pinheiros River, a vital consdition to make it possible to use Tietê's water.
\end{abstract}

\section{Keywords}

Flood, urbanization, electrification, modernization, concession. 


\section{Introdução}

Urbanização e industrialização são processos correlatos; um se explica no outro. E, por seus efeitos se espelham o que se entende por modernização. Modernização, em verdade, é um processo de ordem geral que transforma as bases da sociedade atravessando-a de alto a baixo e implica em sucessivas rupturas. Pode-se ilustrar esse pensamento recorrendo ao poeta inglês, T.S.Elliot, quem em versos descreveu o movimento de trabalhadores sobre a ponte de Londres; surpreendeu-se com a força por ele desconhecida capaz de justificar aquela descomunal mobilização de homens que se avolumava seguindo o ritmo do trabalho nas fábricas. Também Friedrich Engels, em A Classe Trabalhadora na Inglaterra, descreve Manchester em sua busca de entendimento da relação entre os tugúrios, a miséria, a sujeira, a riqueza e opulência que a Inglaterra parecia possuir.

Estas referências apenas reiteram que não se trata de indústria antes e poluição com deterioração dos corpos d'água depois. A indústria é o motor da modernização capitalista da sociedade, pois ao mesmo tempo em que consome e transforma trabalho humano, consome e transforma elementos da natureza sob a forma de matéria prima; modifica os equilíbrios dos ecossistemas naturais e libera diferentes formas de resíduos. Produz uma sociedade muito complexa. Portanto, uma coisa é pensar a relação do homem como ser genérico com a natureza (neolítico-paleolítico) e outra coisa é pensar nessa mesma relação no interior de uma sociedade complexa como a sociedade industrial, moderna, capitalista. Alguns autores identificam violência e pilhagem na voraz expropriação mercantil de espaços, de recursos naturais, de tudo que enfim são elementos do mundo natural.

São as formas de expropriação, apropriação e de valorização mercantil desses elementos (a natureza como exterioridade do ser humano), que ocorrendo de modo cumulativo, serão interpretados adiante, como problemas do meio ambiente. E, geralmente, tudo se passa como se tivesse tido geração espontânea. Sabemos que não se trata disso. Estas são as premissas do raciocínio que se segue.

Quando se trata de refletir sobre as implicações do processo de modernização na estruturação da cidade de São Paulo, logo sobressai o problema do aproveitamento hidrológico da Bacia do Alto Tietê, que em suas diferentes seções, está ligado a diferentes propósitos. Seja ao abastecimento, à utilização da força hidráulica para produzir hidroeletricidade e até como condutor de dejetos.

As dificuldades do escoamento superficial, em face da forma como os rios foram integrados ao processo de modernização social pela indústria em São Paulo, geraram um crônico problema de escoamento superficial como são as enchentes periódicas que ocorrem por ocasião das chuvas de verão no Brasil meridional. Embora, pelo momento, estejamos vivendo a experiência de uma longa estiagem, o que, aliás, não muda a natureza dos problemas relativos ao ambiente fluvial de São Paulo, apenas os agrava.

Na sequência desta exposição, faz-se aqui uma genealogia de certos processos e são identificados os seus agentes, no sentido de refletir sobre os desafios do tempo histórico em relação ao escoamento superficial na Bacia Hidrográfica do Alto Tietê (BAT).

\section{Genealogia}

O primeiro meio século da República é um tempo de grandes transformações; a historiografia fez importantes registros no plano político e social. Esse período é marcado por eventos e estruturas até então desconhecidos o que induziu pensar na modernização capitalista das cidades e nas formas de viver.

A base do processo de modernização, em geral, é a inovação. E ela está geralmente circunscrita por um monopólio (pelo qual se exerce função de dono) que garante a difusão da inovação e capitalização.

Sabe-se que em meados do século XIX uma conjunção importante combinou conhecimento científico, tecnologia e capital, que se desdobrou nas inúmeras invenções em ciência e tecnologia. No interior de estruturas industriais potentes foram gerados e difundidos produtos que marcaram o período conhecido 
por Segunda Revolução Industrial (refino do petróleo, hidroeletricidade devido ao aperfeiçoamento dos processos de transmissão da corrente elétrica, entre outros).

Assim, a ciência transformada em tecnologia para ser aplicada nos processos produtivos gerava disputas por patentes e royalties. Os Estados nacionais funcionavam como retaguarda necessária para viabilizar o movimento do conhecimento através das empresas portadoras das invenções, do dinheiro e do capital, lastreado por grandes organizações financeiras como eram os bancos nesse período.

O processo correlato de urbanização e industrialização, em boa parte devido aos efeitos da expansão da cafeicultura na região de São Paulo, criou certas estruturas materiais e de negócios que favoreceram a forma de uma economia pecuniária, como condição favorável à The São Paulo Tramway Light anda Power Co. Ltd., ou simplesmente Light, para começar operar no Brasil; pois a "Light pertence, sem dúvida, a esse grupo de empresas característico da época do capital financeiro: não apenas uma empresa estrangeira de energia implantada no Brasil, mas parte de um grande conglomerado financeiro e industrial, cujos interesses alcançam não apenas o Canadá e o Brasil, mas também os Estados Unidos, a Inglaterra e, talvez, outros mercados financeiros de importância na época"1.

A Light no Brasil, operou sob o regime de concessão de serviços públicos, que era obtida junto às câmaras municipais. Essa empresa instaurou um processo de compras e aquisições de outras empresas menores que já produziam eletricidade e também de outros serviços urbanos. Mas foram os negócios ligados à produção e distribuição de energia elétrica que se avolumaram e levaram à concentração do capital do setor já nos anos vinte.

Por outro lado, essas inovações técnicas do sistema elétrico pressupunham inscrição territorial porque a matéria prima a ser transformada nessa indústria era o potencial das bacias hidrográficas. Tratava-se da apropriação de um bem natural cujo acesso implicava todas as mediações da sociedade, em contextos que o Estado nacional é o nexo da formação social específica. Por isso que a Light se apresentou com uma carta patente, que a nosso juízo, além de ser uma garantia de mercado significava também a retaguarda que lhe dava o Império Britânico, nas relações com o Estado Brasileiro. Mas, não menos importante para os negócios que a Companhia Light desenvolveria no País, era o contexto de relações políticas no qual se envolvia com as oligarquias locais.

Em São Paulo a industrialização progredia aceleradamente e a produção de hidroeletricidade em escala foi um dos suportes essenciais.

A ingerência da Light na elaboração do Código de Águas (entre 1904 e 1934)², as políticas territoriais definidas no interior da empresa, o staff de juristas internacionais e nacionais, os lobbies em todas as esferas da administração pública além das relações com a imprensa da época convergiam para a continuidade de um processo de formação de capital. 0 que, em princípio, é diferente da reprodução capitalista, pois esta ocorre quando há condições sociais gerais para a competição intercapitalista no circuito do ramo em que atuam as empresas. Por décadas, o grupo Light operou no Brasil e consolidou seu monopólio.

\section{A cidade da Light}

Ao se iniciar o século XX, é maciça a presença de imigrantes estrangeiros em São Paulo para serem conduzidos às lavouras de café. São eles majoritariamente italianos. Consta que pelo menos $25 \%$ dos imigrantes não chegaram às fazendas de café, tendo permanecido na própria cidade. Pierre Monbeig identificou São Paulo como mercado de homens exatamente no momento em que a cidade toda, com seus bairros, tanto aqueles já definidos como outros em formação, se tornavam canteiro de obras da Companhia Light. Pois ela assentava trilhos de bondes, canalizava o gás,

\footnotetext{
${ }^{1}$ Saes, 1987 p24.

${ }^{2}$ Conf. os estudos de Bárbara Levy Sem referncia.
} 
colocava poste, estendia os fios elétricos e de telefonia, distribuía força motriz para indústrias e empregava um enorme exército de trabalhadores. A Light estava em todo lugar. Nesse início do século XX, a cidade de taipa seguia sendo substituída pela São Paulo de tijolos e de cimento e a Companhia Light era identificada como agente modernizador. Os circuitos da economia urbana ganhavam extensão com os bondes de tração elétrica e a iluminação elétrica se tornou o produtomercadoria cobiçado nas residências e nas ruas com a iluminação pública.

A Light, através dos serviços urbanos, inaugurou um novo padrão de uso da cidade. Era a cidade dos fazendeiros de café sendo pensada de fora, segundo os projetos e os interesses das "Companies". Até os anos vinte, quando há um pequeno surto industrial, o trabalho fabril que motivava o deslocamento dos operários, se fazia sobretudo pela ferrovia, porque as fábricas estavam localizadas em posição lindeira às ferrovias. Da década de vinte em diante, os bairros são mais claramente definidos e a cidade propriamente dita é o lugar privilegiado para as articulações de natureza diversas; é o lugar dos confrontos, das decisões, da política. Nessa geografia particular tudo converge para a cidade. 0 prédio da Light, na extremidade do Viaduto do Chá, chegou a ser uma referência na cidade de São Paulo porque estava sempre em pauta, servindo aos encontros e aos desencontros, convergência de festa e de protestos. Todos os consumidores de eletricidade em São Paulo, para lá se dirigiam mensalmente com a finalidade de saldar suas contas de consumo de energia elétrica. Naquela cidade que crescia vorazmente já às primeiras décadas do século, trabalhar na Light chegou a ser condição de distinção social porque a Light representava a ordem do mundo do trabalho ou, melhor dizendo, a ordem da sociedade do trabalho em formação e portadora, evidentemente, das ambigüuidades que lhe eram próprias. Contingentes de população recém egressa dos campos, nacionais e estrangeiros, procuravam um lugar na cidade. Escusado é dizer que os estrangeiros tinham precedência. Pesquisas bem delimitadas sobre essa questão mostram que havia um contingente dos sem-trabalho na cidade à procura de alguma ocupação. E que o contexto de vida urbana mesmo quando não cria o emprego comporta certos expedientes que concorrem na formação de um circuito de dinheiro entre os pobres como ocorria na cidade de São Paulo, desde muito cedo.

Os bondes da Light integraram o cotidiano da cidade e impregnavam o imaginário social. Foi tão notória essa presença a ponto de ter sido com naturalidade incorporada à linguagem e à poética da cidade. Foi motivo de músicas de carnaval, de versos do poeta Mário de Andrade e também de Sérgio Milliet. Tão presente foi a Light, que persistem ainda expressões singulares vindas à tona, vez por outra, para dizer:

— e eu com a Light?
— não sou sócio da Light!
— hei moço, olha o bonde! seu condutor din-din, um pra Light e dois pra mim!

Porém, se a luz para iluminar as casas, as ruas e o bonde para circular na cidade integraram a poética da cidade, integraram também o drama traduzido ora nas reações contra as tarifas, ora contra a manutenção dos veículos, ora contra acidentes frequentes, assim por diante. A Light foi interpretada também como uma pedra no caminho do movimento nacionalista. E todo o processo da Light no Brasil foi acompanhado de certa consciência crítica contestadora do monopólio que praticava. Os conflitos entre Light x Guinle, de que trata Alexandre Saes (2013), exemplificam esse estado de coisas.

A pesquisa em arquivos e jornais não foi suficiente para dar conhecimento de que os interesses da Light geraram uma questão acerca do Rio Pinheiros. Foi preciso investigar os próprios arquivos da Companhia Light para refletir sobre o assunto.

\section{A questão do Rio Pinheiros}

A Companhia Light operando sob o regime de Concessão de Serviços Públicos, empreendeu as transformações ocorridas no Rio Pinheiros, as quais consistiam em canalizar, alargar, retificar aprofundar e inverter os leitos dos rios Pinheiros e de seus formadores (Grande e Guarapiranga), a jusante das respectivas barragens nos municípios de Santo Amaro e da Capital, drenando, 
beneficiando e saneando os terrenos situados nas respectivas zonas inundáveis. Para tanto, deveria construir represas, eclusas, estações elevatórias com aparelhagem convenientemente alimentadas por correntes elétricas, construir usinas geradoras auxiliares no Guarapiranga e, no alto da serra, no canal de ligação dos reservatórios do Rio Grande e das Pedras, podendo também conduzir para o reservatório do Rio Grande as águas aproveitáveis da Bacia do Tietê. Em função do objetivo principal, que consistia em captar águas aproveitáveis do Tietê, teria que inverter o curso original do Rio Pinheiros e foi por esta razão desencadeado um processo que se estendeu por mais de trinta anos.

A Lei no 2249 de 27 de novembro de 1927, concedia direitos a The São Paulo Tramway Light and Power Company Limited, de captar águas diretamente do Tietê para lançá-las na vertente oceânica da Serra do Mar realizando a reversão do curso original do Rio Pinheiros. A regulamentação da lei seria em seguida estabelecida por contrato celebrado entre o Governo do Estado e a Light. 0 Decreto estadual n.4487 de 9 de setembro de 1928 aprovou as cláusulas, em execução desta Lei.

Certas indefinições foram sendo sobrepostas nos termos dos referidos contratos. Uma delas diz respeito às zonas inundáveis; outra diz respeito à indeterminação do que seriam águas aproveitáveis do Rio Tietê. Enquanto a zona inundável diz respeito a um domínio territorial, à superfície na qual a Companhia exerceria seus direitos de concessionária, relativamente às águas ficava em aberto o problema de saber qual a extensão do aproveitamento, em termos de volume das águas do Tietê; questão jamais equacionada.

Já relativamente ao que seria propriamente a zona inundável, as cláusulas desse contrato prescrevem o direito da Companhia Light em desapropriar para fins de utilidade pública os terrenos destinados a alargar a Represa do Rio Grande e para fins de necessidade pública, desapropriar terrenos que não tinham ainda um uso prescrito, como os terrenos situados na zona inundável, ou abaixo do limite da máxima enchente, na várzea do Rio Pinheiros, tendo em vista a execução dos projetos, mas deveria a Companhia submeter a aprovação do governo a planta dessa área com indicação dos seus limites.

0 mesmo contrato evocava o instituto da retrocessão e determinava que a Companhia efetuasse desapropriações por direito de cobrar o custo integral dos benefícios introduzidos na área e que ao término das obras haveria de levar as propriedades (desapropriadas) a hasta pública (leilões), a partir de um preço mínimo. Esta condição tinha o sentido de impedir que a Companhia incorporasse livremente ao seu patrimônio terras desapropriadas e de assegurar um preço mínimo para que, supostamente, antigos proprietários tivessem alguma chance de reaver suas propriedades. Há aqui uma contradição nos termos: preço mínimo de terras valorizadas pelos investimentos jamais estariam ao alcance das economias dos desapropriados, dada a natureza das ocupações correntes nas várzeas. Além disso, o objetivo inicial das negociações é o aumento da disponibilidade de energia. Por isso os investimentos previstos constituem aplicação de capitais produtivos no setor de energia elétrica que seriam, em princípio, valorizados nesse circuito de produção-consumo.

Tendo por base esse contrato, restava também o problema de saber o que era o custo integral dos benefícios introduzidos na zona beneficiada e que zona era essa. Em verdade, a Companhia fixou a necessidade de cobrar benefícios, porque operava uma racionalidade em certa medida avançada, ou seja, introduzia a noção das melhorias urbanas geradoras de rendas. Era a compreensão de que as obras em projeto ao mesmo tempo em que integravam o circuito do capital produtivo, na sua forma material permaneceriam fixadas no território e como tal provocariam mudanças nos padrões de uso, com possibilidade de captação de parte da mais valia que circula pela sociedade. Isso porque as propriedade adjacentes às obras em projeto acumulariam um sobre-preço, ou uma renda diferencial, derivadas dos investimentos projetados na produção de energia. De tal forma que em decorrência do lógico processo de valorização das propriedades planejou a Companhia um modus operandi que lhe permitisse orientá-lo.

Mas a Companhia Light iniciou seus negócios no Rio Pinheiros não propriamente pelas obras. Iniciou-os pela compra de vastas propriedades, antes mesmo de 1928, e pela demarcação da linha perimétrica de enchente, para definir no terreno sua área de jurisdição, definida pelos limites da Enchente de 1929, em 
São Paulo no mês de fevereiro. Esta foi uma estratégia de valorização bem pensada e executada no interior da Companhia.

Cabe assinalar que não havia documentação suficiente para saber, no terreno, o que seria a linha de máxima enchente em 1928, quando foi firmado o contrato entre o Governo do Estado e a Companhia e no qual ficou estabelecido o território de domínio para a circunscrição de todos os direitos referidos no contrato.

A pesquisa empreendida em diferentes fontes, inclusive a análise de registros pluviométricos, permitiu concluir que os limites territoriais foram estrategicamente concebidos em meio a uma situação de desastre, em fevereiro de 1929. Após um período chuvoso, as águas existentes nas várzeas foram acrescidas dos volumes das represas da Light após terem sido abertas as comportas para acrescer o volume retido por processos naturais e assim seria superestimado, como de fato foi, aquela superfície admitida como planície aluvial do Rio Pinheiros. Uma vistoria ad perpetum demarcou no terreno, o território de domínio da Companhia, pela fixação dos marcos territoriais. Assim foi delimitada a zona inundável, identificada também nos mapas da Companhia, como linha de máxima enchente.

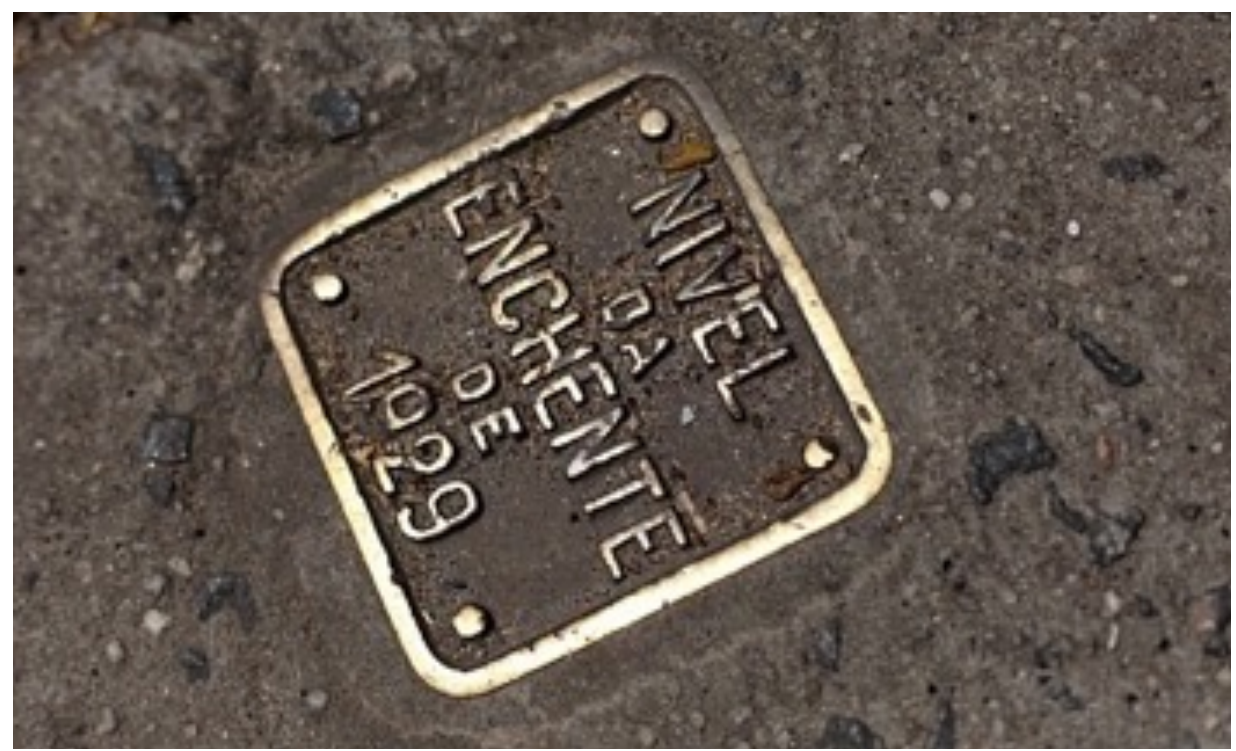

Figura 1. Marco da enchente de 1929. Foto: Natália Russo / AE.

A partir desse momento, as questões com terra ganham grandes proporções nos negócios da Companhia em São Paulo, tanto que foi criado um Departamento de Terras do Pinheiros, além do que, para a Companhia surgia o problema de transformar um monopólio de direito em monopólio de fato sobre as terras delimitadas, pois que ali havia usos correntes, tais como as olarias, a extração de areia, tanto do rio como das várzeas, com importantes pontos de comercialização; as hortas, as pastagens dos animais, a pesca, além do uso lúdico através dos esportes náuticos e também do jogo de futebol.

Não foi sem luta que a Companhia Light instaurou na zona de enchente um processo de concentração da propriedade ao seu favor. Amparada que estava pela Lei da Concessão, pôs-se em campo através de acordos, de desapropriações judiciais tanto amigáveis como litigantes, por vezes simples compra, até assegurar-se da propriedade de todas as terras situadas abaixo da linha de enchente. Embora a Companhia tenha tido que enfrentar longos e duros embates. Entretanto, antes mesmo que fossem baixadas as cláusulas que regulamentaram a concessão, já se constituía a Light na maior proprietária de terras no Rio Pinheiros, pois que na área que circundava as represas já havia feito aquisições no montante de $6.461 .211 \mathrm{~km}^{2}$.

Os grandes proprietários de terras entraram em complicados acordos com a Companhia Light e, os órgãos da administração pública presentes nessas relações, em geral atuaram em favor do truste. Com honrosa exceção um grupo de engenheiros da Prefeitura de São Paulo resistiu bravamente às imposições que lhes apresentava o staff da Light. 
Existiam grandes propriedades ao longo do Rio Pinheiros que adentravam pela várzea e tinham o rio por limite. Era o caso da Companhia City, empresa inglesa que desde 1914 fazia grandes aquisições de terra na cidade de São Paulo e promovia loteamentos residenciais. No Rio Pinheiros, fizera aquisições tanto à margem esquerda como à margem direita. Idem, Dumont Villares que planejava a criação do Distrito Industrial do Jaguaré; a Companhia Votorantim se transformou em grande proprietária no Brooklin, a Companhia Cidade Jardim, entre o rio e as colinas do Morumbi, entre outras grandes propriedades.

Ao longo do Rio Pinheiros, ao final da década de vinte, quando as gestões para execução de obras estavam em franco processo, existiam loteamentos que formavam certos bairros, alguns modestos outros nem tanto. Destes loteamentos, também o Rio Pinheiros era um limite, de modo que porções importantes de áreas ocupadas com moradias estavam situadas abaixo da linha da máxima enchente, demarcada em 1929. Como era o caso de Vila Leopoldina, Pinheiros, Itaim, Vila Olímpia, Vila Funchal, Santo Amaro e Capela do Socorro, com a terra parcelada em lotes $\left(200,300,500\right.$ a $\left.600 \mathrm{~m}^{2}\right)$ e em muitos casos, subdivididos para o uso. Era uma multiplicidade de proprietários, os quais foram acionados judicialmente para que deixassem suas moradias, já então, objeto dos processos de desapropriação movidos pela Companhia Light.

As terras do Estado, tais como as da Prefeitura do Município de São Paulo e do Instituto Butantã, além das terras do leito velho do Rio, que em princípio são públicas, entraram também em demandas.

A Companhia enfrentou esses proprietários de diferentes formas, tendo entre 1929 e 1937 executado os projetos técnicos e montado o seu Departamento de Terras do Pinheiros a partir do levantamento de todas as propriedades da várzea, desde a confluência com o Rio Tietê até as represas, em Santo Amaro.

Com as obras em andamento, a Light pleiteou junto à administração pública que lhe fossem transferidas as terras correspondentes às alças de meandros que passavam a orlar as duas margens do canal do Rio Pinheiros em decorrência da canalização-retificação do curso do rio, que, como se sabe, era originalmente meândrico. A Companhia foi prontamente atendida sob a condição de que: "realizado o entupimento desses leitos, devem eles ser vendidos, conjuntamente com os terrenos adjacentes, em hasta pública, nos termos e para os fins do contrato que regula a venda dos terrenos beneficiados". Mais uma vez, entenda-se por beneficiados, todos os terrenos valorizados com as obras em execução. Ora, a Light era a maior proprietária de terras no Rio Pinheiros, por isso a Companhia pretendia a anexação pura e simples. Foi então que, impetrado recurso, indicou ao Judiciário o dispositivo do Código de Águas - fundamentado no direito reinol de Portugal, segundo o qual, "o leito velho de um rio passa a pertencer a quem, autorizado, abre um novo leito artificial". Ora, interessou ao lobby do Código de Águas expressar dessa maneira os interesses da Light, pois quem estava interferindo no funcionamento das bacias hidrográficas era a própria Light. Através dessa contestação a Companhia anexou aos seus domínios $1.875 .000 \mathrm{~m}^{2}$ de terrenos da várzea do Rio Pinheiros.

Essa ação lobista foi documentada em memorando interno da Companhia assinado por Mr. Billings, no qual recomendava que nenhum advogado da própria Companhia fosse encarregado de impetrar tal recurso; para encarregar-se do caso, haveria de ser contratado um jovem advogado, reconhecido nos círculos de São Paulo, a quem bastaria aplicar os dispositivos do Código das Águas.

Em suma, as concessões para explorar serviço público eram acompanhadas de contratos para regulamentar as relações, atribuições e as atividades. Envolviam complexos contratos que em certos casos deram à Companhia condição equivalente ade um Estado, principalmente no que se refere à mobilização de população e às desapropriações que realizou. 0 direito em promover desapropriações foi praticado amplamente em áreas de concessão de serviços públicos, nas quais fazia valer a distinção entre utilidade pública e necessidade pública, esta última como condição necessária à execução de obras e a primeira, destinada à implantação das suas estruturas técnicas. Os estudos sobre essas intervenções no Rio Pinheiros demonstraram como o princípio da necessidade pública era elástico e como podia ser amplamente considerado nas estratégias de capitalização da Light. 


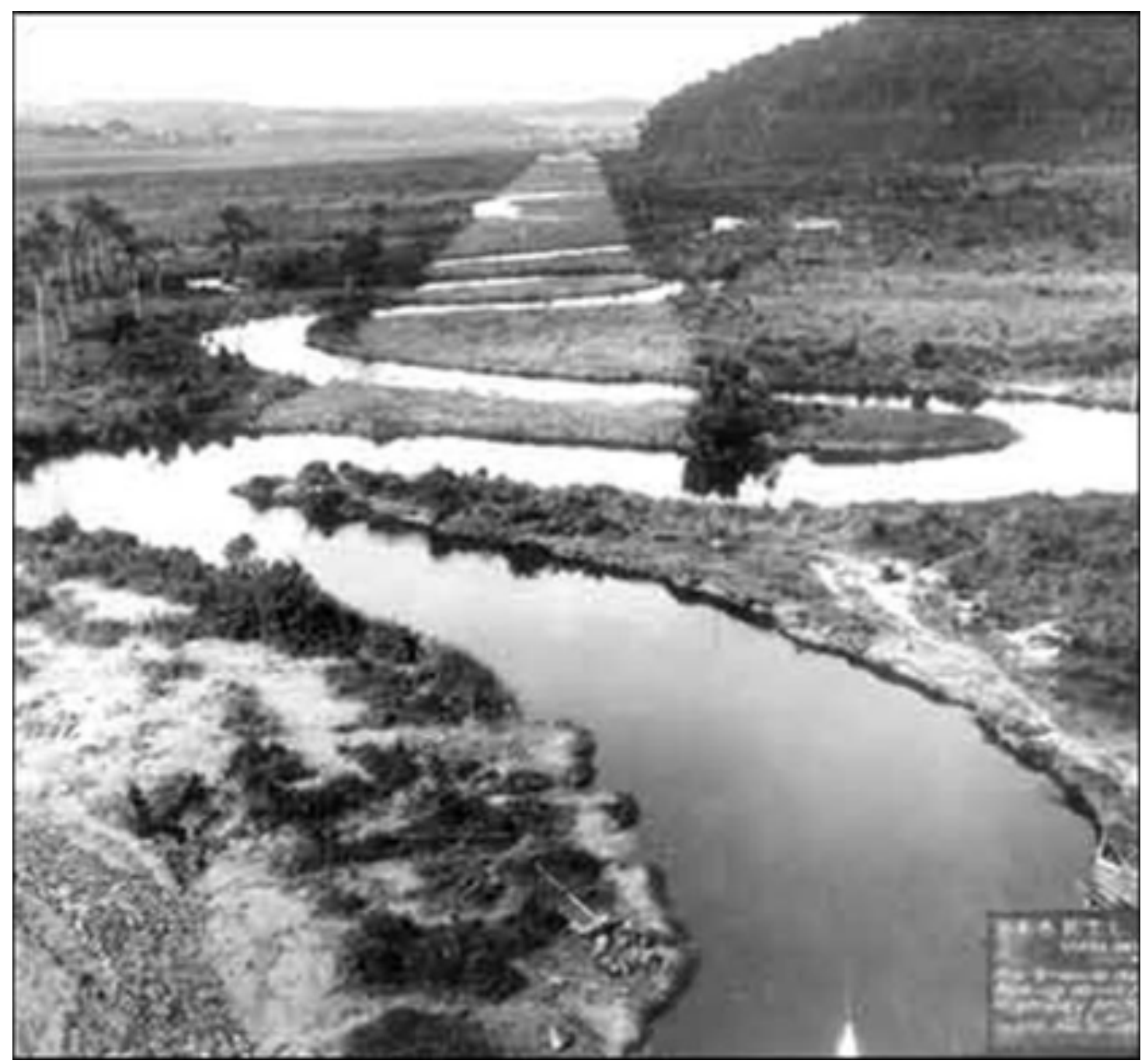

Figura 2. Meandros e linhas de demarcação do novo canal do Pinheiros. Fonte: Departamento de Patrimônio Histórico da Eletropaulo (Arquivos da Light).

À medida que se encaminhavam as questões com as propriedades, como sempre mais demoradas, iam acontecendo acordos, compra, venda, tomada de posse e a desarticulação das atividades que envolviam o rio e as várzeas.

Uma primeira grande intervenção que atingiu certas atividades no Rio Pinheiros foi o represamento do Rio Guarapiranga (em 1907) porque mudou o regime do rio. Processos judiciais foram instaurados contra a Light por barqueiros tiradores de areia; Rabelo \& Cia., empresa que retirava areia do fundo do leito e tinha pontos de comercialização nas margens do rio, em processo contra a Light alegou que quando a água da represa era lançada no rio e aumentava repentinamente o volume de água, eram eles pegos de surpresa, seus barcos viravam, a água subia no nível dos seus depósitos acumulados às margens do rio e então perdiam o trabalho executado durante dias ou semanas. Até os peixes começaram a morrer, e a água assim revolta já não servia para beber. Portanto, a intervenção na cabeceira, ou seja, no Rio Guarapiranga, tinha a propriedade de modificar o regime do rio e modificar os ecossistemas naturais do rio e das várzeas. 0 progresso material estava em questão.

Como já assinalado, restava ainda que o monopólio de direito chegasse a ser um monopólio de fato. É então instituída a figura do fiscal de terras cuja função era enunciar o domínio absoluto da Light a todos que de alguma forma usassem o rio ou as várzeas do Rio Pinheiros. Com os grandes proprietários, as questões geralmente se encaminharam pela forma de acordos nos quais os benefícios a serem criados eram pagos mediante a doação de grandes extensões de terras à Companhia. Com os moradores dos lotes urbanos foi, geralmente, pela via das desapropriações judiciais que os processos se encaminharam. Com o poder público, longas demandas culminaram em soluções diferentes 
entre a Companhia e a Prefeitura do Município de São Paulo (que jamais reconheceu os supostos direitos da Light), e a Companhia e o Instituto Butantã, este que, por doação pagou os benefícios.

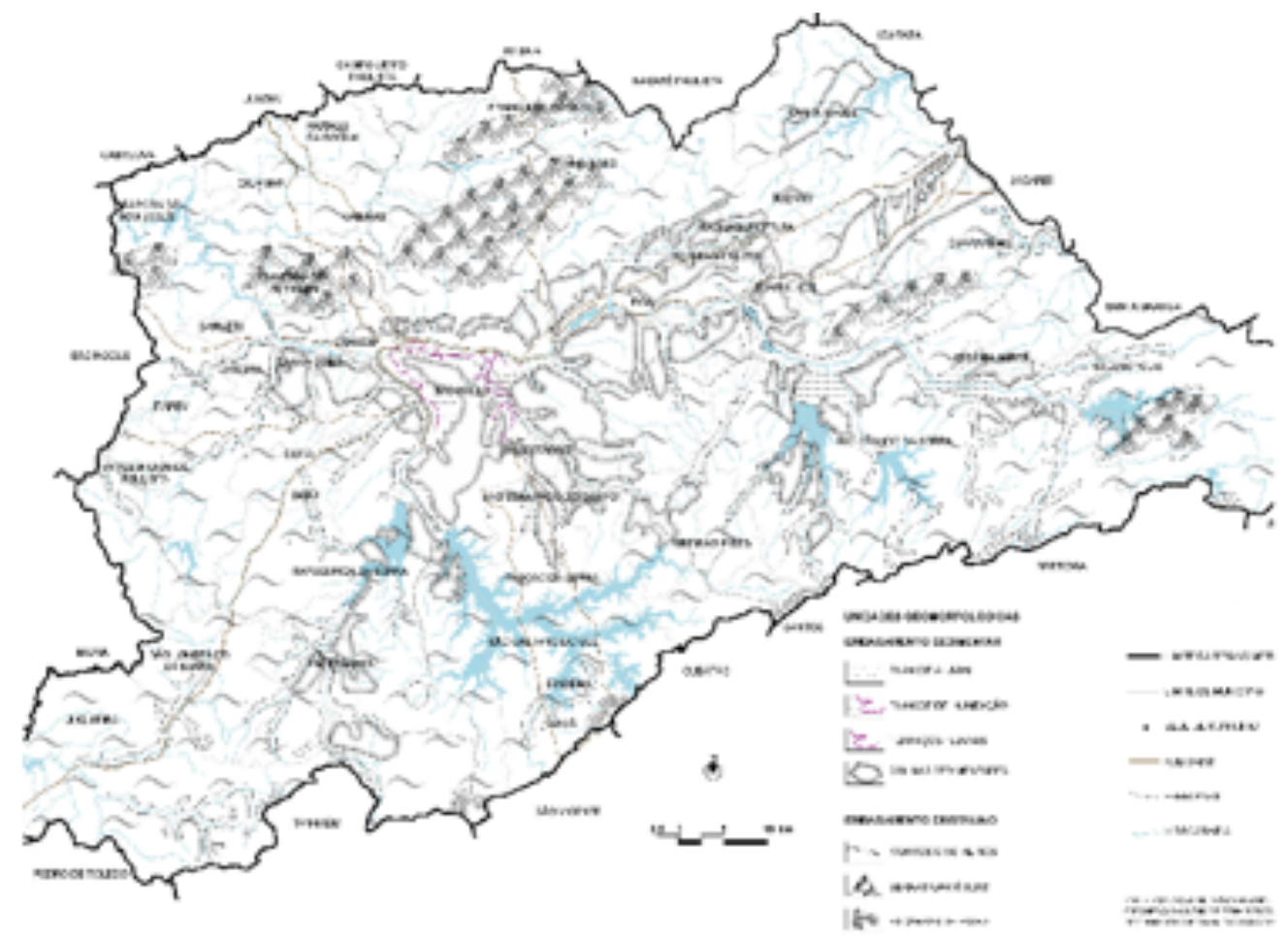

Figura 3. Mapa geomorfológico da Região Metropolitana de São Paulo .Fonte: Emplasa,1994 (Ab’Saber, 1967; F. Almeida, 1963), organizado por: Cinthia Cristina Batista.

Há registros de respostas de natureza diversa às práticas em curso manifestas em recursos para revisão de valores das indenizações por desapropriação; denúncia de citações não efetuadas; reações individuais, por vezes violentas, que se dirigiam tanto ao fiscal de terras como aos oficiais de Justiça. Chegou-se à criação de uma organização de moradores contra a Light, no bairro do Itaim Bibi, que recorreu ao Presidente da República contra a Light. Como este já era um momento avançado do processo, as decisões da hasta pública e retrocessões reclamadas pelos moradores não firmaram jurisprudência para o conjunto da área.

De um modo geral, entre as reações isoladas estavam atitudes que pretendiam negar os processos pela recusa de levantamento dos depósitos feitos em juízo e até pela oposição física, a admitir a tomada de posse pela Companhia de suas moradias. O domínio de fato, por parte da Companhia no Rio Pinheiros era cada vez maior. Avolumavam-se nos escritórios da Light os pedidos de permissão para utilização do rio e das várzeas do Rio Pinheiros. Eram pedidos para cortar lenha, levar o gado a beber água, pastar cabras, pescar no rio, empinar papagaio, jogar futebol nas várzeas, aos quais se deu invariavelmente resposta negativa, sob alegação de que não se poderia perturbar o andamento das obras. Sobre todos os pedidos decidia pessoalmente Mr.Billings.

Doações, desapropriações judiciais, desapropriações amigáveis que funcionavam como compra e venda e o pagamento em dinheiro dos benefícios incorporados às propriedades, eram as modalidades de contratos-acordos vigentes na década de trinta.

\section{Condicionantes estruturais}

As graves enchentes que assolam a cidade de São Paulo foram sendo gradativamente compreendidas como consequência do aproveitamento hidrelétrico da Bacia do Alto Tietê. A esse propósito, as controvérsias ocuparam extensas colunas dos jornais cotidianos; argumentos contrapostos tanto isentavam a Companhia Light por suas obras de quaisquer implicações, mas até havia quem afirmasse 
que se não fossem os objetos técnicos implantados pela Companhia, as enchentes seriam ainda mais graves em suas consequências. Mas correntes de opinião por vezes fundadas em pareceres técnicos responsabilizavam in limine a Companhia pelos graves episódios de enchentes, principalmente porque através das estruturas montadas a empresa tinha poder de controlar as vazões.

Pretende-se aqui, expor o problema a partir de uma ligeira consideração sobre os elementos do sítio urbano da cidade de São Paulo e sobre as estruturas técnicas que deram forma ao sistema Light de geração e transmissão.

Para o segmento do curso do Rio Tietê, que no sentido leste-oeste, atravessa a área urbana de São Paulo, convergem rios, riachos e córregos de diferentes calibres formadores da rede hídrica. Este setor do planalto que é identificado como Bacia Sedimentar de São Paulo, é formado por depósitos recentes (quaternários) responsáveis pelo preenchimento do fundo, acrescido de leve soerguimento, os quais levaram à formação de extensas planícies aluvionais por onde escoam os principais rios da bacia: Tietê, Pinheiros e Tamanduateí; rios que são de natureza meândrica, de longo curso, com extensas planícies aluviais e de fraca declividade; o Rio Tietê, entre as cidades de Penha e Osasco apresentava, originalmente, uma queda inferior a $10 \mathrm{~cm} / \mathrm{km}$, sendo esse mesmo segmento do curso de 46.000 metros; as planícies conhecidas popularmente como várzea ou vargem perfaziam perto de 30 milhões de $\mathrm{m}^{2}$ de terrenos somente no Rio Tietê, porque, se somados os terrenos da várzea do Rio Pinheiros, tem-se uma superfície de 55 milhões de $\mathrm{m}^{2}$.

Tais atributos do sítio urbano foram amplamente considerados na montagem do sistema elétrico de São Paulo, o que propõe a necessidade de discutir os meios técnicos e as estruturas fixadas no território, cuja implantação modificou profundamente o meio natural pelas alterações provocadas no ambiente fluvial.

Em 1901, tem-se o aproveitamento de uma pequena queda de água no Rio Tietê, com a construção da Barragem-Usina de Santana de Parnaíba, distante $33 \mathrm{~km}$ da capital e gerando $20.000 \mathrm{~kW}$.

Em 1925, foram construídas outras duas usinas, ainda no Tietê: a de Porto Góis, em Itú e depois a de Rasgão, em São Roque (1925).

Em 1911, o Rio Sorocaba foi integrado ao Sistema Light com a compra da Usina de Ituparanga. Uma empresa de caráter regional, que ao ser incorporada a Light, foi registrada em Toronto como São Paulo Electric Serviços de Eletricidade (1912).

Em 1907, tendo em vista a pressão da demada por energia em face ao crescimento da indústria e às necessidades postas pela urbanização, com a finalidade de manter o nível da Barragem de Santana de Parnaíba, entrou em operação a Represa do Rio Guarapiranga, um dos formadores do Rio Pinheiros, naturalmente afluente do Tietê. De tal forma que, o volume represado seria naturalmente escoado para o Rio Tietê no período de estiagem, mantendo-se assim, em funcionamento a usina instalada.

Em 1926, o represamento do Rio Grande (um dos formadores do Rio Pinheiros), permitiu que fossem desviadas as águas para o Rio das Pedras, já no alto da serra, onde foi construído o reservatório do Rio das Pedras e colocasse em funcionamento a Usina de Cubatão, produzindo $44.437 \mathrm{~kW}$. Corria o ano de 1947 quando seria redimensionada a capacidade geradora de Cubatão com a construção da usina subterrânea. A capacidade instalada foi de 2.000.000 de kW.

Em suma, a Barragem de Santana de Parnaíba construída em 1901, a primeira obra da Light no Tietê, fora sempre apontada como o principal condicionante das graves enchentes. 0 rebaixamento da crista dessa barragem em 1,0 m fora recomendado pelo eminente sanitarista Saturnino de Brito em 1926, no estudo realizado junto à Comissão de Melhoramentos do Rio Tietê. Tal orientação visava melhorar o fluxo do Tietê. No entanto, como assinalado, a barragem não foi rebaixada e acabou sendo elevada em 6 metros para permitir o funcionamento das usinas subterrâneas.

Em verdade, havia uma contradição perpassando todo esse processo: a produção de energia exigia que os rios, no caso Tietê e Pinheiros, estivessem sempre no nível que interessasse ao sistema de 
geração. Contraditoriamente, para que os episódios de chuvas não implicassem no drama das enchentes teria sido necessário manter o regime natural com as superfícies reguladoras dos fluxos. Mas desde que os represamentos estavam feitos para fins de controle de cheias, as represas deveriam permanecer vazias no período chuvoso, ou pelo menos aquém do programado. 0 que jamais seria possível.

Tudo faz pensar que não se pode destacar quaisquer que sejam dos objetos técnicos aqui assinalados. Trata-se de um sistema integrado de geração, transmissão e distribuição de energia, num contexto específico, sendo apenas nestes termos que tais implicações podem, eventualmente, serem esclarecidas. Nos anos trinta, o espaço das águas como são as planícies aluviais, enquanto elemento regulador do fluxo hídrico, já são objeto da ação interesseira dos agentes que atuam na produção do espaço urbano. A própria Companhia Light organizava nesse momento suas ações no Rio Pinheiros com vistas a inserir as várzeas nos circuitos da economia urbana, ou melhor dizendo de sua própria economia.

Os usos urbanos das várzeas do Rio Tietê e do Rio Pinheiros, que se anunciavam vorazmente desde os anos trinta e o sistema elétrico que se consumou com a construção da usina subterrânea, trazem os elementos do processo que se pretendeu desvelar. Bem compreendeu todo o problema o engenheiro Catulo Branco, que se valendo de informações colhidas junto à Companhia Light na época que era concluído o alteamento da barragem de Santana de Parnaíba, declarou que "em consequência dessa obra, o remanso das águas se estenderá a todo trecho do Rio Tietê fronteiriço à cidade de São Paulo, para além da barra do Rio Pinheiros, alcançando quase o nível de Guarulhos".

\section{Questões do escoamento superficial}

Enquanto a Companhia executava a sequência de obras que comporia o Sistema Light de Geração e Transmissão de Energia, o governo municipal ocupou-se do Rio Tietê. Antes porém, já ao final do século XIX, uma primeira abordagem do Rio Tietê coube à Comissão de Saneamento do Estado no âmbito das concepções higienistas. É quando os doutores do corpo (médicos) indicam aos doutores do espaço (os engenheiros sanitaristas) que os pântanos deveriam ser drenados e o espaço saneado como medida de controle de epidemias.

Com esse sentido, para sanear a várzea do Carmo, foram projetadas e executadas obras no Rio Tietê e como a implantação das ferrovias acabou por valorizar longos trechos dos baixos terraços e várzeas para usos urbanos entre a cidade e o rio, acabou por vingar o propósito de retificar o Rio Tietê. Nos anos vinte, foram feitos estudos completos sobre o Rio Tietê no âmbito da Comissão de Melhoramentos e foi apresentado o projeto do sanitarista Saturnino de Brito, que propôs a construção de canais de escoamento e lagos com função reguladora do fluxo hídrico. Pelos anos trinta, a Prefeitura do Município de São Paulo assumiu os trabalhos de retificação do Rio Tietê com base no Projeto Cintra.

Ao longo dos anos e mesmo de décadas, à medida que as obras seguiam sendo executadas, fenômenos de enchentes ocorriam periodicamente. Saturnino de Brito distinguiu enchente de inundação. Identificava as várzeas de inundação como próprias dos rios, advertindo que tomar as várzeas aos rios é estabelecer o problema das enchentes.

Tem sentido apenas ontológico afirmar que as várzeas pertencem aos rios quando nos referimos à BAT, porque os rios foram canalizados e as várzeas transformadas em espaço de circulação, não sem antes integrarem o circuito urbano da riqueza como objeto de mercantilização.

\section{Atualidade dos problemas}

O Projeto Tietê, de 1994, foi concebido em meio a grande mobilização cuja bandeira era a de salvar o Rio Tietê da poluição e controlar as cheias; envolveram-se no movimento alguns meios de comunicação, agentes da sociedade civil e governo, contando com valioso aporte de recursos do governo japonês. 0 principal produto obtido com essa mobilização foi o rebaixamento da calha do Tietê em $2,5 \mathrm{~m}$ e o alargamento das margens com revestimento dos taludes. A capacidade de vazão no complexo viário Heróis de 1932 (popularmente conhecido como "Cebolão") seria de 
$1050 \mathrm{~m}^{3} / \mathrm{seg}$. contra $640 \mathrm{~m}^{3} / \mathrm{seg}$. naquele momento. Esse plano recomendou medidas para bloquear o uso e ocupação das várzeas: que fossem evitados projetos de canalização de riachos e córregos porque acelerariam o fluxo hidráulico e que fossem criadas condições de amortecimento das cheias a montante da capital pela retenção de excedentes de água.

Orientação que denota inversão nas concepções até então vigentes. Então, se a questão é a de falta de espaço para as águas, devem elas permanecer onde caírem. É esse o fundamento da vazão de restrição, pela qual fica estabelecido o limite físico de expansão e aumento da capacidade hidráulica para os principais cursos drenantes da BAT. Presume-se que o funcionamento de estruturas de detenção como, por exemplo são os piscinões, permitam a vazão de restrição.

Trata-se, em verdade, da emergência de um novo paradigma que abriu a oportunidade para novos encaminhamentos sem poder desconsiderar os problemas acumulados, como a poluição dos corpos d'água e as enchentes periódicas.

Para controlar as enchentes, entrou em execução o Plano da Macrodrenagem (com horizonte para 2020), e para combater a poluição das águas, políticas específicas destinadas a controlar a poluição industrial tiveram sucesso, mas os rios continuam poluídos porque a maior carga poluente $(70 \%)$ é de origem doméstica. Portanto está relacionada ao modo de consumir e de viver.

Mas todas as iniciativas parecem pequenas em face dos enigmas criados a partir da forma histórica do aproveitamento da Bacia do Alto Tietê. No limite, a adoção de tais procedimentos indica que o funcionamento da Bacia chegou a um ponto crítico. Um ponto de não retorno. As soluções propostas têm que assimilar a história, não há como desfazer o feito.

\section{Referências}

PONTES, José Alfredo O.V. 0 Brasil na Visão da Light. São Paulo: Memória São Paulo, n.7.

PROCURADORIA GERAL. Abusos do Poder Econômico: Light e Estado da Guanabara. Revista de Direito, separata nํㅇ, Rio de Janeiro, 1960.

SAES, Alexandre M. Conflitos do Capital. Bauru: Edusc, 2010.

SAES, Alexandre M. Light versus CBEE: Energia Elétrica na Formação da Industria Brasileira (1900-1920). in CASALS y CAPEL (org.). Capitalismo e história da eletrificação, 1890-1930. Barcelona: Ediciones del Serbal, 2013.

SAES, Flávio. Café, Indústria e Eletricidade em São Paulo. História \& Energia, São Paulo: Eletropaulo/ Departamento do Patrimônio Histórico, 1986. p.21.

SEABRA, Odette C. de Lima. Os meandros dos rios nos meandros do Poder. Tietê e Pinheiros: valorização dos rios e das várzeas na cidade de Paulo. Tese de doutoramento. São Paulo: FFLCH/USP, 1986. 